\title{
iGerman-Turkish Identity in Fatih Akin's Head-On: Transgressing Gender Boundaries, Redefining Home and Belonging
}

\section{Verena von Eicken, York}

Fatih Akin's internationally acclaimed film Gegen die Wand/Head-On (2004), one of the key works of contemporary Turkish-German cinema, interrogates and complicates conceptions of homeland, ethnicity and gender. Head-on shows that our sense of home is shaped as much by cultural customs as by the place we live in. Its lead character Sibel (Sibel Kekilli) rejects the home her parents are offering because she finds its religious and cultural customs oppressive and irreconcilable with the liberties she enjoyed growing up in Germany. She moves to Istanbul, where she experiences complete freedom, but also complete isolation and alienation, failing to belong. This chapter analyzes the film's poignant take on the experiences of young Turkish-German women forced to negotiate conflicting feelings of home and belonging. It argues that at the end of the film, Sibel achieves a self-chosen identity by defining herself not against her family background, but independently from it, and that she does so through roleplay and a performance of gender, of different versions of both femininity and masculinity. Furthermore, it demonstrates how the Istanbul location is used in the film to explore the protagonist's complex relationship with her country of origin, and to illustrate Sibel's journey towards independence.

Head-On (in German Gegen die Wand, literally 'Against the wall'), directed by the acclaimed Turkish-German filmmaker Fatih Akin, was the first German film in eighteen years to win the Golden Bear for Best Film at the 2004 Berlin International Film Festival, and was named 'Best Film' at the 2004 European Film Awards. Its success is representative of a development which has seen films by directors with a Turkish background, such as Thomas Arslan or Yüksel Yavuz, gain a firm place in German cinema.

It is perhaps no coincidence that some of the first and most influential films addressing the situation of Turkish immigrants in Germany also dealt with a woman's fate: 40m2 Deutschland/40 Square Meters of Germany (1986, dir.Tevfik Başer) tells the story of Turna, a young woman, who, after her arrival in Hamburg from Turkey, is imprisoned in her own apartment by her husband. Yasemin (1988, dir. Hark Bohm), on the other hand, has its heroine achieve independence and liberation from her despotic father by escaping with her German boyfriend and and severing all ties with her family. The filmmakers who addressed the experiences of Turkish immigrants in the 1970s and 1980s often focused on Turkish-German girls and women at the centre of the conflict between their families' allegedly archaic and oppressively patriarchal structures as well as on the more liberal German society in which 
they lived. Rob Burns used the term 'cinema of the affected' to describe these films, 1 since they often took a patronizing stance towards immigrant cultures, portraying them as backward, narrow-minded and cruel towards their inferior female members and provided "narratives of rescue, liberation and Westernization"2.

Head-On offers an infinitely more complex portrait of its young Turkish-German heroine, who is very strong-willed and actively shapes the course of her own life, despite encountering various obstacles. Unlike the characters associated with the 'cinema of the affected', Head-On, as Stephen Brockmann explains, "treat[s] its protagonists as self-directed individuals trying to negotiate their own personal and social problems."3 Set in Hamburg, the film tells the story of Sibel (played by Sibel Kekilli), a woman in her twenties and a daughter of Turkish immigrants. Unable to endure her life being controlled by her strict and overbearing father, she attempts suicide. In a psychiatric clinic, she meets 44-year-old Cahit (Birol Ünel), who also sought to end his life. Sibel convinces him to marry her, since his Turkish background would satisfy her parents, yet give her independence. Despite it being a marriage of convenience, the couple initially finds comfort in each other's company. However, their fiery temperaments and self-destructive tendencies ultimately lead to their separation and at the end of the film, both start new lives in Turkey.

Head-On offers a fresh perspective on the Turkish diaspora that constitutes the biggest group of what German policy makers have labeled 'people with a migration background'. There are about 2.5 million people of Turkish origin living in Germany, constituting around three percent of the country's total population.4 In her review of Head-On for the weekly newspaper Die Zeit, Katja Nicodemus observes that the film offers an accurate picture of this contemporary nation of which German-Turks are an integral part:

this Germany, for which [...] directors like Fatih Akin [...] and actresses like Sibel Kekilli stand, does not need to be constructed by the cinema anymore. One might ignore it, but one might equally ignore Cologne Cathedral or the Siegessäule. This Germany is there, it is the only possible ones.

1 Rob Burns, "Turkish-German Cinema: From Cultural Resistance to Transnational Cinema?," in German Cinema After Unification, ed. David Clarke (London, New York: Continuum, 2006): 127-149, 148.

2 Deniz Göktürk, "Turkish Women on German Streets: Closure and Exposure in Transnational Cinema”, in Spaces in European Cinema, ed. Myrto Konstantarakos (Exeter: Intellect, 2000): 64-76, 66.

3 Stephen Brockmann, A Critical History of German Film (Rochester: Camden House, 2010): 480.

4 Jan Hanrath, "Vielfalt der türkeistämmigen Bevölkerung in Deutschland. 50 Jahre Abwerbeabkommen mit der Türkei," Aus Politik und Zeitgeschichte 43 (2011): 16-21, 16.

5 "Natürlich muss jenes Deutschland, für das nicht nur Regisseure wie Fatih Akin, Thomas Arslan und Schauspielerinnen wie Sibel Kekilli stehen, vom Kino nicht mehr gemacht werden. Man kann sich weigern, es zur Kenntnis zu nehmen, doch genauso könnte man den Kölner Dom oder die Siegessäule ignorieren. Dieses Deutschland ist da, es ist das einzig mögliche", Katja Nicodemus, "Ankunft in der Wirklichkeit" [19 
The film's matter-of-fact portrayal of Turkish-Germans in Hamburg prompts Nicodemus to suggest that in Head-On, "the balancing act between familial constraint and urban socialization [...] has moved into the background"6. However, this is an assessment with which I do not fully agree, because the pressure and ultimately, complete rejection, Sibel experiences for not meeting her family's expectation to be obedient and docile is the reason for her extreme distress and rebellion, and it is central to the formation of her identity, which is at the heart of the film.

The origins of the first generation of the so-called guest workers still contribute to the illiberal outlook of some Turkish-German families today. 2011 marked the fiftieth anniversary of migration from Turkey to Germany, which began in 1961, when the German government signed labor recruitment agreements with Turkey. Many of the men recruited were unskilled workers, since the jobs they were hired for, such as operating machines, assembly line work and other factory jobs, did not require specific skills.7 Psychologist Ferah Aksoy points out that "most families who came in the sixties came from traditionally conservative rural regions," 8 and her conversations with young Muslim women in Germany suggest that "many have hardly budged from their values" until the present day.9 They live in communities that consider the family to be the most important social unit, its honor and reputation being central. Controlling and violent behavior of Turkish-German men towards their wives, daughters and sisters often harks back to a code of honor originating from Turkish villages that demands the man to act if the woman's honor is compromised.10 In order to safguard the woman's honor, her virginity needs to be protected, which requires women to dress appropriately and, in some cases, limit her contact to men outside the family circle. If she fails to adhere to these principles, the woman risks not only damaging her honor, but also that of the family. As Angelika Königseder and Birgit Schulze explain,

February 2004], Die Zeit <http://www.zeit.de/2004/09/Berlinale-Abschluss> [acc. 4 September 2013]

[Unless otherwise noted, all translations are my own].

6 "Der Spagat zwischen familiärer Eingebundenheit und Großstadtsozialisation [...] rückt [ ] allerdings in den Hintergrund” (Nicodemus, “Ankunft in der Wirklichkeit”).

7 Deniz Göktürk, David Gramling and Anton Kaes, Germany in Transit: Nation and Migration, 1955-2005 (Berkeley: U of California P, 2007): 9.

8 Qdt. in Göktürk, Gramling and Kaes, Germany in Transit, 172.

9 Qtd. in Göktürk, Gramling and Kaes, Germany in Transit, 172.

10 Angelika Königseder and Birgit Schulze, "Türkische Minderheit in Deutschland," in Vorurteile. Information zur politischen Bildung 271 (2006), Bundeszentrale für politische Bildung <http://www.bpb.de/izpb/9698/tuerkische-minderheit-in-deutschland?p=all> (acc. 4 September 2013). 
the first generation of labor migrants, whose stay in Germany was supposed to be temporary, clung to this value system. Opening up to German society seemed unnecessary and was also difficult, because the majority of migrants did not come from big cities with a strong western influence, but mostly from rural Anatolia, where old traditions had remained valid for centuries 11.

It is the persistence of these traditions and family structures that Sibel suffers from in HeadOn. However, as I mentioned earlier, throughout the film she is portrayed as proactive and in charge of her own life, despite the strictures and the denigration she experiences at the hands of her brother and father.

Therefore, I want to argue that Head-On offers a progressive and empowering representation of a young Turkish-German woman. I will demonstrate how, through a painful and complex process of personal development, Sibel achieves independence and a self-chosen identity, which she does through role-play and a performance of gender, namely of femininity as well as of masculinity. Sibel's experimentation with gender roles is a reflection of the conflicting social mores and views on female equality held by her conservative, religious parents and the more permissive German society in which she grew up. While her parents and the Turkish-German community they belong to are part of a Turkish diaspora that can be defined as "a migrant group[ ] who have left [its] homeland but who continue[s] to share a religious, ethno-national, or national identity" 12 which markedly differs from that of the host nation, Sibel's cultural and personal identity is still in flux. Head-On illustrates her process of constructing a home and sense of belonging for herself that takes into account both her experience of living in Germany with migrant parents, and her return to her parents' homeland, which initially is anything but a home to her. The cities of Hamburg and Istanbul function as sites of Sibel's identity formation, both corresponding to a definition of the diasporic location by Jopi Nyman, who observes that

the diasporic location [...] can be seen as a liminal space of identity, as a space where various [...] forces, both global and local, remould identity. In this sense, diasporic identity can be addressed as a form of hybridized identity, as it is in this space of in

11 "Die erste Generation der Arbeitsmigranten, deren Aufenthalt in Deutschland nicht auf Dauer angelegt war, hielt an diesem Wertesystem fest. Eine Annäherung an die deutsche Gesellschaft schien nicht erforderlich und war zudem schwierig, weil ein Großteil der Zuwanderer nicht aus den westlich orientierten türkischen Großstädten kam, sondern meist aus dem ländlich geprägten Anatolien, wo die jahrhundertealten Traditionen weiterhin ihre Gültigkeit behielten”, Königseder, Schulze, “Türkische Minderheit in Deutschland".

12 Girish Daswani, "The Anthropology of Transnationalism and Diaspora", in A Companion to Diaspor and Transnationalism, eds. Ato Quayson and Girish Daswani ([Online:] Wiley-Blackwell 2013): 29-53, 36. 
betweenness where the diasporic subject reconstructs itself, problematizing the issues of home [and] belonging. 13

The negotiation of conceptions of 'home' and 'belonging' is evident in Akin's representation of Turkey in Head-On, which, as this chapter will demonstrate, refuses to idealize the country as a lost homeland in a way that is typical of recent narratives of migrant experiences: "the notion of home is rearticulated in post-colonial narratives of diaspora and migration, and its link with some mythical geographical homeland is severed"14. Instead, the film uses the Istanbul location both as a manifestation of the protagonists' fraught relationship with their country of origin, and as the site of Sibel's experience of a newly and independently defined home, corresponding to an understanding of home common to diasporic fiction, whose "meaning $[\ldots]$ is $[\ldots]$ found in the future-oriented project[ ] of constructing a sense of belonging in a context of change and displacement" (Papastergiadis, 1998, p. 9).15

\section{Turkish-German femininity in Head-On: Transgressing cultural and gender boundaries}

We first encounter Sibel in a sexually suggestive pose [00:06]16. Wearing a tight red top, black eyeliner and red lipstick, she sits with her elbows resting on her knees, showing her décolleté, and confidently reciprocates Cahit's gaze with a knowing half-smile. A close shot of her bandaged wrists reminds us of her attempted suicide that stands in stark contrast to the vivacity and strength communicated by her look and pose. But this is not a serious decision to end her life: as Jana Burgerová points out, Sibel's "suicide attempt in its ambivalence must be seen as an outcry against the strictures imposed by her father and brother, as well as an attempt to communicate to her family the strong attachment especially to her mother" 17 (Aysel Iscan), the only family member who is sympathetic to her plight. Sibel finds it unbearable to be controlled and policed for doing what would be completely acceptable for the German girls whose company she grew up in. Yet she must suffer brutal chastisement, explaining to Cahit that when her brother (Cem Akin) caught her holding hands with a boy, he broke her nose [00:13].

13 Jopi Nyman, Home, Identity, and Mobility in Contemporary Diasporic Fiction (Amsterdam: Rodopi, 2009): 22.

14 Nyman, Home, Identity, and Mobility, 25.

15 Nikos Papastergiadis, Dialogues in the Diasporas: Essays and Conversations on Cultural Identity (London: Rivers Oram, 1998): 9.

16 These numbers indicate the hours and minutes of the film's running time at the time the scene takes place.

17 "Ihr Selbsttötungsversuch ist in seiner Ambivalenz sowohl ein Aufschrei gegen die erlebten Einschränkungen, zugemutet durch Vater und Bruder, als auch ein Versuch, dem Elternhaus ihre Verbundenheit insbesondere mit ihrer Mutter laut mitzuteilen”, Jana Burgerová, “Gegen die Wand. Migration im Film," Forum der Psychoanalyse 24 (2008): 96-103, 97. 
Rather than wanting to die, Sibel is keen to live life to the fullest. In one of the most frequently quoted lines from the film, she states: "I want to live, Cahit. To live and to dance and to fuck! And not just with one guy"18 [00:13]. She openly pursues sexual adventures and uses a rough, vulgar language that degrades women. "In her gender-sepcific disorientation, she acts like a man"19, as Burgerová observes. Sibel assumes an identity and demeanor that negate her experiences as a woman and verbally perpetuate the abusive mindset of the men around her. At the same time, Sibel opts for a markedly feminine appearance in order to attract men. At this point in the film, she is unable to develop a conception of self for example based on her abilities or the achievement of economic independence. Instead, Sibel takes on an identity based on rejecting and rebelling against everything her parents and her culture are demanding of her. Polona Petek points out that "Sibel's desire for freedom from the constraints and expectations of her atavistic family appears to be directed towards a singular goal - unbridled promiscuity rather than emancipation or acquisition of social, economic and/or cultural capital." 20 Her fake marriage to Cahit gives Sibel the freedom she longed for, and in the following months, she and Cahit enjoy a life of partying, drugs and sex with different partners.

Sibel's libidinous lifestyle in this part of the film is offset, however, by a scene in which she prepares a traditional Turkish meal for Cahit. Sibel's process of self-discovery and of finding her own identity is informed both by her Turkish background and the German surroundings. Maha El Hissy notes that "the crossing of boundaries in Head-On is characterized by role play and the oscillation between conformist and non-conformist identities"21. For Sibel, trying out different identities through masquerade and role play is a means of negotiating between the identity her parents assigned to her, that of the dutiful daughter and future housewife, and the life she wants to live, emotionally and sexually independent. This process of role playing and the oscillation between expected and rebellious behavior is epitomized by the dinner scene. In a montage sequence accompanied by Turkish vocal music, Sibel buys food and drinks, and we see her preparing stuffed peppers [00:52]. There are close shots of her hands cutting vegetables, stuffing the peppers, preparing a red

\footnotetext{
18 "Ich will leben, Cahit. Ich will leben, ich will tanzen, ich will ficken! Und nich' nur mit einem Typen."

19 “In ihrer geschlechtsspezifischen Orientierungslosigkeit gebärdet sie sich wie ein Mann ”, Burgerová,

"Gegen die Wand. Migration im Film," 97.

20 Polona Petek, "Enabling collisions: Re-thinking multiculturalism through Fatih Akin's Gegen die Wand/Head On," Studies in European Cinema 4.3 (2007): 177-186, 181.

21 "Kennzeichned für die Grenzüberschreitung in Gegen die Wand sind das Rollenspiel und das Wechseln zwischen konformen und nonkonformen Identitäten”, Maha El Hissy, "Transnationaler Grenzverkehr in Fatih Akins Gegen die Wand und Auf der anderen Seite", in Von der nationalen zur internationalen Literatur. Transkulturelle deutschsprachige Literatur und Kultur im Zeitalter globaler Migration, ed. Helmut Schmitz (Amsterdam and New York: Rodopi): 169-186, 173-174.
} 
sauce and laying out a colorful tablecloth with Cahit's help. The strong colors of the food greens, reds and oranges - and the fact that we see Sibel blending the filling with her hands make the sequence a very visceral experience to the viewer, and one that is very positively coded. The preparation of food that we see has a life-affirming quality, conveying a warmth and comfort that contrasts with the images of squalor in Cahit's apartment, the grimy interiors of the bars and pubs the two frequent, and the cold, clinical environment of the psychiatric clinic. It suggests that the characters do not experience Turkish traditions and customs solely as restrictive and stifling, but that they also function to provide a sense of home and belonging. Petek comments on this scene by saying that "Cahit and Sibel [...] develop a genuine, and not disabling, appreciation for their culture of descent. It is an appreciation [...] encapsulated in culinary delights" 22 .

The montage also contains a shot of Cahit approvingly watching Sibel's efforts. It captures the moment in which his affection for her, which we saw growing in previous scenes, is cemented. Yet by the end of the scene, Cahit will be storming out of the apartment in anger. It is worth considering what exactly happens between these two moments. Significantly, Cahit's feelings for Sibel culminate in a moment in which she assumes the role of a Turkish housewife, emulating a traditional way of life that Cahit has so far vehemently rejected. Now he praises Sibel's cooking and her performance of the 'wife' role by saying that "marrying you wasn't such a bad idea" 23 [00:53]. Sibel declares that she learned the recipe from her mother [00:53], which further underlines that in cooking this meal, she conforms to the behavior expected of a Turkish woman, continuing a family custom that is passed on from generation to the next. She then goes on to say that her mother asked her about children, to which Cahit, in his enthusiasm, responds: "Let's make some [babies]"24 [00:53]. At this point, Sibel abruptly breaks with the housewife role and reasserts her desire for absolute independence by bluntly rejecting this proposition [00:53]. She explains that should her mother get too insistent, she could always say that Cahit was impotent, which would also be a good reason for a divorce. She then insults Cahit's feelings further by asking if they will go to their local club that night, implying that there she will meet someone for casual sex, which we have seen her do before. This sequence illustrates how Sibel temporarily assumes an identity and behavior that she has learned from her family, but only as long as this does not conflict with her demand for complete personal and sexual independence that is key to her new, chosen identity. Her changeful behavior suggests that, rather than being clear about who she

\footnotetext{
22 Petek, "Enabling collisions," 183.

23 "[W]ar keine schlechte Idee dich zu heiraten."

24 "Lass uns doch welche machen."
} 
is and how she wants to live, she is very much in a state of transition. El Hissy calls this state of transition a 'liminal phase' and points out that 'this liminal phase is [...] marked by a certain ambiguity and shows how the character[ ] exhibit[s] characteristics of the old, as well as the new phase"25. Sibel willfully ignores Cahit's feelings for her and hurts him by making clear that she prefers the company of other men to his. Her defensiveness suggests the fragility of the new identity that she has chosen for herself, and that she feels is endangered even by committing to a caring partner who has proven that he will not curtail her freedom.

The pair's shared life ends abruptly when Cahit smashes one of Sibel's lovers over the head with an ashtray, thereby killing him [01:06]. Having fallen in love with Sibel, Cahit could not contain his jealousy when being provoked by the rival. As a consequence, Sibel is cut off from her family and lives in fear of them avenging what they see as her guilt and shameful behavior. The following morning, Sibel spots her brother in the street and runs away from him as soon as their eyes meet, narrowly escaping him as he follows her [01:10]. He had threatened her already in the beginning of the film after her suicide attempt, saying that "if anything happens to [their father because of his grief and worry over Sibel], you will be dead meat"26 [00:10]. The murder Cahit commits places Sibel in a situation where she is not only deprived of any support or comfort from her family, but also has to expect physical violence or worse from her own brother. The identity of dutiful Turkish daughter, which she performed in front of her parents in marrying Cahit, and which she re-enacted in the dinner scene, is now irredeemably lost to her.

Sibel takes up her cousin Selma's (Meltem Cumbul) offer to live with her in Istanbul. Once there, Sibel abandons her markedly feminine appearance from the Hamburg scenes, in which she had long hair and wore either short skirts or tight jeans that highlighted her female curves. She now looks very masculine, having her hair cut short and wearing baggy trousers and a bomber jacket [01:15]. In a voiceover, Sibel explicitly states that she is not living, but merely surviving in Istanbul, and likens her life to Cahit's experiences in prison: "you pulled the short straw, but jail is the only thing I can compare my life to here"27 [01:21]. The depiction of the city in the early Istanbul scenes underscores Sibel's feelings of alienation and isolation. Most of these scenes take place at night, and show Sibel moving either through empty streets or walking past other people who take no notice of her and whom she does not

\footnotetext{
25 "Diese liminale Phase ist [...] durch einge gewisse Ambiguität gekennzeichnet und zeigt, wie die Charaktere Züge der abgeschlossenen, aber auch der neuen Phase in sich vereinen”, El

Hissy, “Transnationaler Grenzverkehr”, 173.

26 "Wenn dem Alten was passiert, wisch ich dich weg"

27 "Du hast das härtere Los gezogen, doch Gefängnis is das einzige, was mir einfällt, wenn ich an mein Leben hier denke."
} 
interact with. Akin here repeatedly uses wide, high-angle shots, which show Sibel in a crowd of people, making her look small and forlorn. The depiction of Istanbul as anonymous and of Sibel as isolated demonstrate that "she $[\ldots]$ is [...] an 'exile' - banished from her diasporic home as well as from her ethnic homeland" 28 , as Petek rightly observes. She is often pictured walking alone in dark back alleys of Istanbul, which are portrayed in the film as a maledominated territory in which women are vulnerable to sexual assaults. These back streets provide the setting for one the most striking scenes of the film, in which Sibel gets into a fight with a group of men. Müller-Richter comments on this scene by saying that "it is particularly noticeable that Akin opts to have scenes of excessive violence always set in [...] so-called backstages, and also in moments that primarily concern the breach of spatial boundaries or the breach of [...] masculine territoriality" 29 . Sibel finds herself in a liminal space populated by hotel and service staff as they leave work through the back door, but also by thugs and drug dealers. It is a liminal space also in the sense that here she undergoes a temporary transformation from a feminine' to a 'masculine' persona, in order to be able to meet the men she encounters as an equal.

The previous scenes have shown Sibel taking opium with a bartender, who rapes her after she has passed out [01:25]. When Sibel leaves the bar and encounters a group of men in a back alley who proposition her, her reaction is somewhat unexpected. In an outburst of rage that seems disproportionate to the provocation, she stops, turns around and shouts at one of the men: "Why don't you go fuck your mothers?"30 [01:26]. She then runs towards him, knees him in the groin and kicks him as he lies on the ground. The other two men rally to his defense, beating and kicking Sibel to the ground. The men then walk away, but Sibel gets up and shouts more insults at them, upon which the man she first attacked walks towards her again. She attacks him a second time, and is again beaten up by his friends. Although she is now severely injured, her face covered in blood, her eyes swollen and her nose broken, Sibel gets up and provokes the men a third time, only for one of them to stab her with a knife [01:28].

Being easily provoked and answering a verbal provocation with physical violence, Sibel emulates a "domineering form[ ] of masculinity characterised by physical control, aggression,

28 Petek, "Enabling collisions," 183.

29 "Es ist überaus auffällig, dass Akin Szenen exzessiver Gewalt stets in [...] so genannten backstages spielen lässt; in Moment, in denen es vorrangig um die Verletzung von Raumgrenzen oder um Verletzungen [...] maskuliner Territorialität geht”, Klaus Müller-Richter, "Phantasmagorien der Rückkehr aus der Migration Fatih Akins kinematographische Konstruktion und Inszenierung von Heimaträumen," in Imaginäre Topographien: Migration und Verortung, eds. Klaus Müller-Richter, Ramona M. Uritescu-Lombard [Bielefeld: transcript, 2007]: 177-194, 186 [Emphasis in original]. 
conquering and competition" 31 . Her body language - she first reacts to the men's calls by smashing her sports bag on the ground and turning around with her fists clenched and her shoulders rounded like a wrestler - and her ruthless fighting style, is stereotypically masculine rather than feminine. As Burgerová observes, Sibel "denies [...] her own female boundaries and fragility in an unconscious suicidal drive." 32 However, explaining her behavior as merely self-destructive or suicidal does not do justice to Sibel's motives in this scene. First and foremost she seeks to avenge the violence and humiliation she suffered at the hands of men; her unbridled rage and defiance exemplified by her overreaction to being provoked and her repeated taunting of the men. Even though she is acting irrationally and self-destructively, as viewers we are struck by Sibel's extraordinary courage and resilience.

Sibel's "gender-crossing masquerade" 33 corresponds to an understanding of gender as performative as contended by queer theory. Judith Butler has argued that the gender categories of 'male' and 'female' are socially learned rather than innate. Butler states that "there is no gender identity behind the expressions of gender; [...] identity is performatively constituted by the very 'expressions' that are said to be its results." 34 Thus, in Butler's view, it is our acquired and internalized behavior and appearance that codes us as distinctly male or female:

a sedimentation of gender norms produces the peculiar phenomenon of a 'natural sex' or a 'real woman' [and] this is a sedimentation that over time has produced a set of corporeal styles which [...] appear as the natural configuration of bodies into sexes existing in a binary relation to one another 35 .

Sibel's performance of masculinity draws attention to the constructedness of gender by breaking up this male-female binary.

Sibel's gender identity in this scene is ambiguous: She fully inhabits a male demeanor and appearance, but her opponents are well aware that she is a woman. The confrontation is started by a man who addresses her by saying "Hey baby? What are you doing out so late?

31 Niall Hanlon, Masculinities, Care and Equality: Identity and Nurture in Men's Lives (Basingstoke: Palgrave Macmillan, 2012): 61.

32 "[L]eugnet in unbewusster suizidaler Absicht [...] die eigene weibliche Grenze und Fragilität", Burgerová, "Gegen die Wand. Migration im Film," 101.

33 For the term "Gender-Crossing-Maskerade," see Ortrud Gutjahr, "Migration in die Ungleichzeitigkeit: Fatih Akins Gegen die Wand und die Wende im deutsch-türkischen Film," in Krisenkino. Filmanalyse as Kulturanalyse: Zur Konstruktion von Normalität und Abweichung im Spielfilm, ed. Waltraud Wende and Lars Koch (Bielefeld: transcript, 2010): 225-249, 245.

34 Judith Butler, Gender Trouble: Feminism and the Subversion of Identity (New York: Routledge, 1990): 25.

35 Butler, Gender Trouble, 240. 
[...] You need a man?"36 [01:26]. Later, the men call her a "fucking slut" 37 [01:27] and tell her: "Watch your mouth, girl"38 [01:27]. At the same time, Sibel's appropriation of a typically masculine brand of verbal and physical aggression prompts the men to treat her as they would treat a male adversary. Their reaction suggests that our perception of gender is influenced as much by a person's behavior as it is by their biological make-up.

Butler proposes to consider gender as an "“act', as it were, which is both intentional and performative, where 'performative' suggests a dramatic and contingent construction of meaning"39. As Gutjahr40 notes, the violent confrontation between Sibel and the men is a reenactment of the abominable physical violations such as the rape that immediately preceded it, but also of Sibel's mistreatment through her male relatives back in Hamburg. Sibel's performance of masculinity has the purpose of holding up a mirror to these abusive forms of hyper-masculinity she has encountered. Gutjahr comments on her verbal provocations, which are less pronounced in the finished film than in the script (which has her say "I fuck your mothers, I fuck your fathers, I fuck your children, I fuck your families" 41 ), by saying that "through her provocations, Sibel reinacts $[\ldots]$ her $[\ldots]$ rebellion against traditional gender roles and ways of life" 42 . Behaving like a man herself allows Sibel to create a new identity as she refuses to be dominated, ordered about, and humiliated by men any longer. Although severely injured, she survives and starts a new life, thus ultimately emerging triumphant.

When Cahit comes to meet Sibel in Istanbul after having served his sentence, he finds her transformed. In Berghahn's words, "Sibel has traded the role of femme fatale for that of mother" 43 . She has renounced the excessive and promiscuous lifestyle that she practiced in Hamburg for a more secure, conventional life with a boyfriend and daughter. Although they spend a few days and nights together [01:43-01:47], Cahit cannot convince Sibel to stay with him, so he embarks on the journey to Mersin alone [01:49]. Cahit's plan to relocate to his birthplace Mersin, motivated by nostalgic memories, and Sibel's decision not to join him are

36 “Güzelim, yavrum sen n’apıyorsun gecenin bu saatinde sokaklarda ha? [...] Canım, güzelim erkek mi istiyorsun ha?" [Trans. Beyza Ates].

"Pis orospu!" [Trans. Beyza Ate].

"Ya kızım, gitsene sen işine ya!" [Trans. Beyza Ates].

Butler, Gender Trouble, 139.

Gutjahr, "Migration in die Ungleichzeitigkeit," 246.

“Ich fick' eure Mütter, ich fick' eure Väter, ich fick' eure Kinder, ich fick' eure Sippen”, Fatih Akin, Gegen die Wand. Das Buch zum Film mit Dokumenten, Materialien, Interviews (Cologne: Kiepenheuer und Witsch, 2004): 156.

42 "Sibel reinszeniert mit ihren Provokationen [...] ihre [...] Auflehnung gegen tradierte Geschlechtervorstellungen und Lebensprinzipien", Gutjahr, "Migration in die Ungleichzeitigkeit," 246.

43 Daniela Berghahn, "'Seeing everything with different eyes': The diasporic optic in the films of Fatih Akin", in New Directions in German Cinema, eds. Paul Cooke and Chris Homewood (London : I. B. Tauris, 2011): 235-252, 247. 
indicative of the ways in which Head-On interrogates the concept of homeland by juxtaposing the different ways in which first and second generation immigrants relate to the place of their ethnic origin.

\section{Complicating conceptions of home and belonging: The representation of Istanbul in Head-On}

Throughout the film, Akin complicates the concept of homeland or Heimat, which is a central theme not only in Head-On, but in several of his other films such as Solino (2002) and The Edge of Heaven (2007), which also feature home-seeking journeys44. It is noteworthy that Akin indirectly addresses the idea of Heimat, since, as Berghahn notes, "Heimat is a quintessentially German theme" 45 , which gained prominence in German cinema during the 1950s with the proliferation of the Heimatfilm. The concept of Heimat, which resists any simple definition, involves a deep feeling of belonging to one's place of origin and its community that is often tinged with nostalgic longing, because one has left it behind or because it has been transformed in some process of modernization. The work of exilic filmmakers often contains a similarly idealized vision of the lost homeland. In his analysis of exilic and diasporic cinema, Naficy uses the concept of the 'chronotopes': "cinematic chronotopes are specific temporal and spatial settings in which stories unfold" 46 , and which are used to depict the homeland and the place of exile. While the homeland is typically presented as a utopian idyll and is associated with open spaces, boundlessness and timelessness, life in exile has a contemporary setting that is presented as a dystopian, claustrophobic, and closed space 47. The depiction of the lost "homeland is cathected by means of fetishization and nostalgic longing for [its] natural landscape" 48 . Head-On refuses to simply reproduce such an idyllic rendering of the lost homeland, which is evidenced by the depiction of the urban space of Istanbul in the film.

The only idealizing visual representation of Istanbul in the film occurs in the six musical interludes, which show actress Idil Üner in a long red dress, singing melancholic songs about unrequited love [00:00; 00:15; 00:45; 01:15; 01:29, 01:50]. These inserts frame and interrupt the narrative flow and comment on the protagonists' feelings via the melodramatic lyrics: "Have all those who love and who have lost their lovers lost their senses

\footnotetext{
44 Daniela Berghahn, "No place like home? Or impossible homecomings in the films of Fatih Akin," New Cinemas: Journal of Contemporary Film 4.3 (2006): 141-157, 145 [Emphasis in original).

$45 \quad$ Berghahn, "No place like home?", 144.

46 Hamid Naficy, An Accented Cinema: Exilic and Diasporic Filmmaking (Princeton and Oxford: Princeton UP, 2001): 152.

$47 \quad$ Naficy, An Accented Cinema, 5, 152-153.

$48 \quad$ Naficy, An Accented Cinema, 5.
} 
like me? [...]/ I lost my mind/ May the mountains rejoice in my stead"49 [01:50]. Akin states that he chose the songs to demonstrate how classical Turkish music addresses heartbreak and excessive passion in a similar way to the western punk music used elsewhere in the film50. Üner is accompanied by the Roma clarinetist Selim Sesler and his ensemble; the ground they stand on is covered with Oriental rugs, the majestic Süleymaniye Mosque and the Golden Horn towering in the background. This panorama is the only setting in Head-On that reproduces the open chronotopes of the homeland, its idyllic scenery and landmarks, which Naficy51 associates with exilic and diasporic filmmaking. However, it does so in a knowing and distancing way. As Landwehr comments, the musical interludes constitute a postmodern rendering of Turkish history that reduces it to stereotypical images: the Istanbul "tableau can be regarded as a self-referential statement on the role of the media, especially film, to alter or even create the images by which people remember a specific time and place" 52 . The static shots of the musicians and the mosque quote other idealized depictions of the city, namely those directed at tourists. Akin himself states that this representation "was a way to break the Western, realistic look of the film with a kitschy postcard element"53. Thus, Akin uses the musical interludes to expose idealized depictions of Turkey, while at the same time they demonstrate the filmmaker's tendency to merge elements of eastern and western culture.

The multifaceted and changing representations of Istanbul throughout Head-On reflect Akin's status as a second-generation immigrant who is influenced by both German and Turkish culture. Born in Germany in 1973 to Turkish parents, Akin is not an exilic or diasporic filmmaker; instead he fits Naficy's category of 'postcolonial ethnic and identity filmmaker'. Naficy writes that "ethnic identity films [...] deal with $[\ldots]$ the conflict between descent relations, emphasizing [...] ethnicity, and consent relations, stressing self-made, contractual affiliations. [...] [they are] concerned with becoming" 54 , that is, the individual's identity formation in their new country. Head-On blurs the boundaries between home and host country - neither Germany nor Turkey are clearly one or the other - but at the same time

\footnotetext{
49 "Herkes sevdiğine böyle mi yanar? [...] / Ben perişan oldum, efendim, aman/Dağlar şen olsun.” [Trans. Beyza Ates].

$50 \quad$ Fatih Akin and Wendy Mitchell, "Going to Extremes: Fatih Akin on His Turkish-German Love Story Head-On," indiewire (2005)

$<$ http://www.indiewire.com/article/going_to_extremes_fatih_akin_on_his_turkishgerman_love_story_head-on> (acc. 13 September 2013).

51 Naficy, An Accented Cinema, 153.

52 Margarete Landwehr, "Liminal Spaces in Fatih Akin"s Gegen die Wand/Head-On: Orientalism vs Globalisation," in Performing Difference: Representations of 'The Other' in Film and Theatre, ed. Jonathan C. Friedman (Lanham: UP of America, 2009): 76-88, 84.

53 Akin and Mitchell, "Going to Extremes," 2005.

54 Naficy, An Accented Cinema, 15.
} 
it emphasizes Sibel's self-chosen affiliation with Istanbul, her new home: she initially feels like a stranger in the city, but by the end of the film, she is settled there.

This process is reflected in the changing representation of Istanbul in the film. During Sibel's initial 'exile,' that is, from the time she is taken in by Selma until she is found by a taxi driver after the climatic fight with the three men, the city is portrayed as anonymous, dark and hostile. But the scenes showing Sibel and Cahit in Istanbul after he has served his sentence portray the city in a much friendlier light. The characters often enjoy panoramic views of Istanbul from a comfortable distance: when Cahit meets Selma at one of the top floors of the Marmara Hotel to enquire after Sibel, his gaze shifts to the windows overlooking the Bosporus [01:37]. Later, Selma, Sibel and her baby are pictured in a brightly lit, spacious flat overlooking the city [01:42], and Sibel and Cahit are seen sitting on a balcony on a sunny afternoon, looking at buildings and the sea below [01:45]. The fact that the protagonists are frequently shown looking down on the city visualizes the degree of mastery over their own lives that they have achieved. Cahit has overcome his alcoholism, which played a part in the murder he committed, and he seems much calmer, even if he is still in search of a place to settle down in. Sibel's situation is mirrored in the two opposing representations of Istanbul in the middle and end sections of the film. She is no longer at risk of being swallowed by its dark streets, but is able to look back at her former, self-destructive actions from a spatial and emotional distance. Head-On thus renounces any simplistic rendering of Turkey as an idyllic homeland. Instead, it uses Istanbul locations to mirror the characters' conflicted and changing feelings, or to knowingly comment on romanticized or clichéd representations of (life in) Turkey.

At the same time, the fact that both protagonists settle down in Turkey at the end of the film is highly unusual for second-generation migrants naturalized in Germany, as Petek55 points out: both Cahit and Sibel are German citizens who had lived in the country for decades. However, the film's ending questions whether Germany ever became a home for its protagonists by suggesting that while Sibel was unable to achieve a fulfilling life in Hamburg, she does so in Istanbul. Indeed Sibel's relationship to Turkey and Istanbul is marked by contradictions that the film never fully resolves. On the one hand, she moved to Istanbul to escape her family, initially has little connection to the city and is very isolated there. On the other hand, Istanbul is the place where Sibel's identity formation culminates after her fight with the men: 'Sibel's symbolic 'death', the beating, and her daughter's birth can be

$55 \quad$ Petek, "Enabling collisions," 180. 
perceived as the death of Sibel's old persona and the birth of a new self" 56 . While the Istanbul setting of these climatic scenes point to the redemptive qualities of Sibel's ethnic homeland Turkey, one might conversely argue that she could lead a life very similar to that in Istanbul in Germany or any other country once she is no longer being controlled by her male relatives and has found a partner who offers her both independence and support.

Akin himself strongly opposes a reading of the ending as an endorsement of Turkey as a lost homeland where German-Turks may find redemption. He states that

what interests me is not the place [Sibel lives at the end of the film], but the situation. She has a man and she has a child. But she is not happy with that. I think [...] [that] all my characters are searching for something. Searching for a better life. [...] [But] whether they find it remains unclear. And in their country of origin they look for redemption. But they do not find redemptions7.

Thus, for Akin, the return to the country of origin alone does not provide a simple solution to his protagonists' problems. This is exemplified by the ending of Head-On, which sees Sibel forced to choose between freedom and security. As Margarete Landwehr points out, "Sibel realizes at the film's conclusion [that] complete freedom doesn't exist as she must choose between her child and her lover." 58 She has to decide whether to stay with her partner or follow Cahit to Mersin.

It is notable that Head-On does not judge Sibel's nights with Cahit in Istanbul in any way or condemn them as morally reprehensible. We do not see her having to answer to her boyfriend about where she is going; not even her cousin Selma, whom she leaves her daughter with, reprimands her for what she is about to do. In fact, Selma gives Sibel her blessing, telling her "I wish you all the best"59 [01:43] as Sibel leaves. Rather, the film stresses Sibel's decision-making process. When she is with Cahit, we see her looking out of the window several times, deep in thought, while back home, we see her packing her suitcase and then having second thoughts as she hears her boyfriend and daughter playing next door [01:48]. The question, then, is how to evaluate Sibel's decision to stay.

56 Landwehr, "Liminal Spaces in Fatih Akin's Gegen die Wand/Head-On", 81.

57 " $[\mathrm{M}]$ ich interessiert nicht der Ort, sondern der Zustand: Sie hat nen Typen und sie hat ein Kind. Sie ist aber nicht glücklich damit. Ich denke [dass] alle meine Figuren [...] auf der Suche [sind]. Auf der Suche nach einem besseren Leben. [...] [Aber] es bleibt offen, ob sie das bessere Leben finden. Und im Ursprungsland suchen sie Erlösung. Aber die Erlösung finden sie nicht" (Fatih Akin, Rüdiger Suchsland, "Ich bin wirklich davon ausgegangen: Ok, das könnte mein letzter Film sein..." [11 March 2004], artechock <www.artechock.de/film/text/interview/a/akin_2004.htm> [acc. 4 September 2013]).

58 Landwehr, "Liminal Spaces in Fatih Akin's Gegen die Wand/Head-On," 86.

59 "Hayırlısı olsun." [Trans. Beyza Ates]. 
In the later Istanbul scenes, Kekilli's speech and body language indicate that Sibel has changed. She appears more calm and serene in the presence of her daughter and Selma [01:42], suggesting that she has achieved a degree of stability and contentment that she was lacking earlier in the film, when she was compulsively striving to live in a way that contradicted everything demanded by her parents and their cultural tradition. Head-On depicts Sibel's struggle not only to liberate herself from her oppressive family but also to relinquish the reckless and self-destructive lifestyle she had adopted as a result of this oppression. By the end of the film, she is able to define herself not against her family background, but independently from it, having started a family of her own: one scene shows Sibel in her apartment with her daughter Pamuk. Sibel casts the child an affectionate look [01:42], suggesting that Pamuk gives her happiness and a new responsibility to care not only for herself, but for the child that is dependent on her.

Scholars differ in their opinions on the degree of fulfillment Sibel has achieved. Brockmann reads the ending as follows: "Sibel [has] trie[d], [...] unusucessfully, to emancipate herself from the patriarchal power of Turkish traditionalism"60, since her life is now defined by precisely the role of housewife and mother that her parents would have envisioned for her. Equally, Berghahn notes that in turning down the relationship with Cahit, which we know would be more fiery and volatile, "Sibel forsakes her sensuality and egocentric pursuit of pleasure for the kind of stable and conventional life she abhorred."61 However, as Berghahn goes on to stress, "the mediocrity of Sibel's new life back in Turkey provides the structure and stability that will keep her alive. And in this sense her homecoming [also] brings about her redemption."62 Similarly, El Hissy argues that "her decision is not to be understood as a sign of her imprisonment, but as a commitment to a civil and familial life and her obligations in Istanbul"63. I agree with these latter readings, firstly because Sibel is given the opportunity to decide freely and independently whether to go or to stay (a choice she did not have when escaping from her family), and secondly since she appears to be much more settled in and in control of her life even before making this decision. Therefore, I would argue that the film is more optimistic about Sibel's situation than Akin is ready to admit.

\footnotetext{
60 Brockmann, A Critical History of German Film, 486.

61 Berghahn, "No place like home?," 155.

62 Berghahn, "No place like home?," 155.

63 "[Ih]re Entscheidung ist [...] nicht als Ausdruck der Gefangenschaft zu verstehen, sondern als Bekenntnis zu ihrem bürgerlichen und familiären Leben und ihren Verpflichtungen in Istanbul”, El Hissy,

“Transnationaler Grenzverkehr”, 179.
} 


\section{Conclusion}

Head-On offers an intriguing and complex account of the identity formation of its TurkishGerman heroine. At times consciously, and at times without knowing, Sibel adopts stereotypical feminine and masculine roles such as the seductive femme fatale, the caring housewife or the rough young man, which she uses as blueprints for behavior and appearance. The ability to try out and then cast off these roles helps her in the process of finding an identity that is not shaped by her family's expectations. In her attempt to distance herself from them, she deliberately violates the rules of what is acceptable for a young Turkish woman, according to her strict family, by rejecting the role of 'woman' altogether and acting like a man. Her performance of masculinity in the fighting scene is particularly fascinating in that Sibel is fully able to match her opponents in their gestures, aggression and fighting skills and thus completely inhabits features commonly associated with masculinity rather than femininity, thereby underscoring Butler's observation that gender identity is fluid and performative.

Sibel takes on this excessive identity defined by promiscuity, rebellion and a body that is able to endure extreme pain inflicted upon it by herself and others in order to counteract her experiences of suppression and confinement. Her decision in favor of a more conventional life at the end of the film suggests that this extreme lifestyle has become redundant as she has managed to construct new familial relationships based on trust, commitment and affection rather than oppression and fear. Head-On's representation of Istanbul largely eschews an idealized representation of Turkey. Akin complicates the portrayal of his country of origin, which in the work of diasporic filmmakers analyzed by Naficy is frequently rendered as a mythic, primordial homeland. The visual representation of Istanbul exposes clichéd images of the city as an oriental paradise by arranging the group of musicians in front of a picture postcard view of its largest mosque. More importantly, the depiction of Istanbul is used to illustrate Sibel's personal development. Initially Istanbul is a locus of anonymity and hostility that functions to demonstrate Sibel's lack of connection with her ethnic homeland and her feelings of loneliness and despair. At the end of the film, the images of Sibel looking down onto a sunny and friendly Istanbul visualize the control over her life she has achieved. Sibel experiences both her darkest hours and her greatest contentment in Istanbul, which suggests that the journey to Turkey has redemptive qualities that Akin himself is unwilling to admit. At the same time, Sibel's process of self-discovery begins already in Hamburg and her move to Istanbul is coincidental rather than intentional. 
Although both protagonists ultimately choose to live in Turkey rather than Germany, Head-On does not so much proclaim the failure of migration as portray the challenges and opportunities faced by people growing up or living with both Turkish and German culture. It shows how experiencing the western lifestyle with all its merits and pitfalls has shaped the characters' identities and affected their perception of their ethnic homeland. While Cahit as a first-generation immigrant retains a romantic image of his birthplace, Sibel has no strong ties to Turkey. She only knows the customs and family structures belonging to a specific time and place in Turkey (the city of Zonguldak which her parents left presumably in the 1960s or 1970s) that her family continues to practice in Germany. Through her character, Head-On problematizes the persistence of archaic family structures in Turkish-German families that have lived in Germany for decades but which, in an effort to preserve their cultural integrity, have ignored the liberalization of German society and female emancipation and are therefore more conservative than many families that live in Turkey. The confrontation of her family's oppressive patriarchal outlook with the female equality Sibel experiences in Germany is the basis for her rebellion against her father and brother. By the end of the film, Sibel has both liberated herself from this familial oppression, and achieved a sense of belonging, having built a new life in Istanbul. Thus, with its affirmative ending, Head-On is a poignant tale of empowerment of its heroine that portrays her throughout as a self-directed person rather than a mere victim, without denying the problem of lingering patriarchal structures within GermanTurkish communities.

\section{Contributor information}

Verena von Eicken has recently completed her PhD at the University of York's Department of Theatre, Film and Television. Verena's PhD research focused on contemporary German film (2000-2014 and ongoing), specifically on a new generation of actresses within the renascent German cinema of the last decade, investigating their performance style in relation to female performers in the history of German cinema, as well as analyzing their films with respect to their representations of national identity and the position of women in post-reunification 
Germany. Her research interests include contemporary German cinema, gender representations in film and television and the figure of the film actor as both performer and star. 